\title{
Reduction Roasting of Tin-Bearing Iron Concentrates Using Pyrite
}

\author{
Ren-jie ZHANG, Lei LI* and Yong YU \\ State Key Laboratory of Complex Non-ferrous Metal Resources Clean Utilization, Engineering Research Center of Metallurgical \\ Energy Conservation and Emission Reduction of Ministry of Education, Faculty of Metallurgical and Energy Engineering, \\ Kunming University of Science and Technology, Kunming, 650093 China.
}

(Received on December 17, 2015; accepted on March 9, 2016; J-STAGE Advance published date: March 31, 2016)

\begin{abstract}
A novel method of reduction roasting of tin-bearing iron concentrates using pyrite $\left(\mathrm{FeS}_{2}\right)$ is proposed, in which hematite in tin-bearing iron concentrates is reduced to magnetite $\left(\mathrm{Fe}_{3} \mathrm{O}_{4}\right)$ and cassiterite $\left(\mathrm{SnO}_{2}\right)$ is transformed to volatile tin sulphide (SnS). In a certain range, tin removal and iron reduction rates both increase with roasting temperature, pyrite amounts and residence time. When pyrite amounts exceed 5.00 mass\%, some of the produced magnetite will be sulfurated to FeS and the evaporation of SnS (g) will also be obstructed. Tin content of the concentrate is decreased to 0.07 mass $\%$ and hematite is reduced to magnetite completely under the conditions of $\mathrm{N}_{2}$ flow rate of $5.00 \times 10^{-6} \mathrm{~m}^{3} / \mathrm{s}$, roasting temperature of $1473.0 \mathrm{~K}$, residence time of $60 \mathrm{~min}$, pyrite addition amounts of 5.00 mass $\%$ and concentrates particle size of $0.075 \mathrm{~mm}$. The roasting products can meet the standard of BF ironmaking, which requires tin content in iron ores less than 0.08 mass \%, and the tin removed can be recycled through smoke dust collection.
\end{abstract}

KEY WORDS: pyrite; tin-bearing iron concentrates; reduction roasting; tin removal; comprehensive utilization of resources.

\section{Introduction}

In recent years, the Chinese iron and steel industry develops rapidly, and the corresponding iron ores external dependence degree has kept high for a long time, going against the industry further development. Besides, complex iron ores containing tin, vanadium, titanium and other nonferrous metals have taken an overwhelmingly dominant position in China nowadays. ${ }^{1-4)}$ Realizing sustainable development of the iron and steel industry, China must use domestic resources to produce a steady source of high-quality iron concentrates.

There is a tin-bearing iron ore which is mainly found in the north region of China. ${ }^{5,6)}$ Tin impurity reduces quality of the corresponding iron concentrates, and these concentrates cannot be used directly as blast furnace iron-making materials. Many approaches were reported to utilize these iron ores and the following findings were obtained. The process of iron ores treated by a joint physical separation process of grinding, reselection, magnetic separation and flotation could not obtain qualified iron concentrates, because tin phases $\left(\mathrm{SnO}_{2}\right)$ were embedded in iron phases and it was difficult for being separated through milling method. ${ }^{3)}$ In the methods of selective sulfurization or chlorination, tin could be effectively separated from iron ores, but the disadvantages which included equipment corrosion, environmental pollution, atmosphere and iron phases in the products hard to control were also apparent. ${ }^{4-12)}$ Using reduction method

* Corresponding author: E-mail: tianxiametal1008@163.com DOI: http://dx.doi.org/10.2355/isijinternational.ISIJINT-2015-717 to treat tin-bearing iron concentrates, tin contents of the products can be decreased lower than 0.01 mass $\%$, but the process is difficult to be extended in industry due to its uneasy controlment. ${ }^{5-11)}$

Pyrite (iron-pyrite, $\mathrm{FeS}_{2}$ ) is the most widely used sulfidizer in the tin-containing materials treatment. The ferrous ion $\mathrm{Fe}^{2+}$, element sulfur $\mathrm{S}$, and the disulfide $\mathrm{S}_{2}{ }^{2-}$ can be formed in the decomposition of pyrite, ${ }^{13)}$ and these products make pyrite possess reductive and sulfide property. Thinking of this, a novel method to reduce hematite in tin-bearing iron concentrates parallel to removing tin using pyrite has been proposed in this study. The tin removed can be recycled through smoke dust collection. Different with the earlier research, a special reductant, such as $\mathrm{C}, \mathrm{CO}$ or $\mathrm{H}_{2},{ }^{5-11,14-17)}$ was not added to the reaction system. The treatment conditions, such as roasting temperature and time, pyrite addition amounts and particle size of the tin-bearing iron concentrates have been investigated.

\section{Experimental}

\subsection{Sample Characterization}

The tin-bearing iron concentrate used in this study was collected from a company in Yunnan province, China. Chemical composition (mass\%) of it is depicted in Table 1. Table 1 shows that the major element present is iron ( 64.85 mass $\%$ ) and tin content is of 0.27 mass $\%$, both being well worth to be reclaimed. "Others" in Table 1 is mainly composed of "O" (existing as $\mathrm{Fe}_{2} \mathrm{O}_{3}$ and $\mathrm{Fe}_{3} \mathrm{O}_{4}$ etc.). Main mineral constituents of the samples, established by X-ray diffraction and EPMA, are reported in Figs. 1 and 2. Fig- 
ure 1 shows that main iron phases of the tin-bearing iron concentrates are $\mathrm{Fe}_{2} \mathrm{O}_{3}$ and $\mathrm{Fe}_{3} \mathrm{O}_{4}$, and mass ratio of them is close to $1: 1$. Figure 2 also shows that the concentrates mainly contain hematite and magnetite, and minor amounts of cassiterite are embedded in iron phases at every size fraction. Pyrite was used as reducing agent and sulfidizer in the roasting process, the $\mathrm{FeS}_{2}$ content of which is over $98.00 \mathrm{mass} \%$.

\subsection{Roasting Experiments}

$100 \mathrm{~g}$ of tin-bearing iron concentrates samples were used in every experiment, and addition amount of pyrite was calculated based on the quality ratio of it to tin-bearing iron concentrates, being range from 0.00 mass $\%$ to 100.00 mass $\%$. After mixed carefully, the mixtures of tin-bearing iron concentrates and pyrite were roasted in a tube furnace in the range of $1073.0-1473.0 \mathrm{~K}$ under $\mathrm{N}_{2}$ atmosphere. After a proper time held, the reactor was pulled out for cooling down and analysis.

\subsection{Characterization}

The thermo gravimetric analysis (TG) and differential

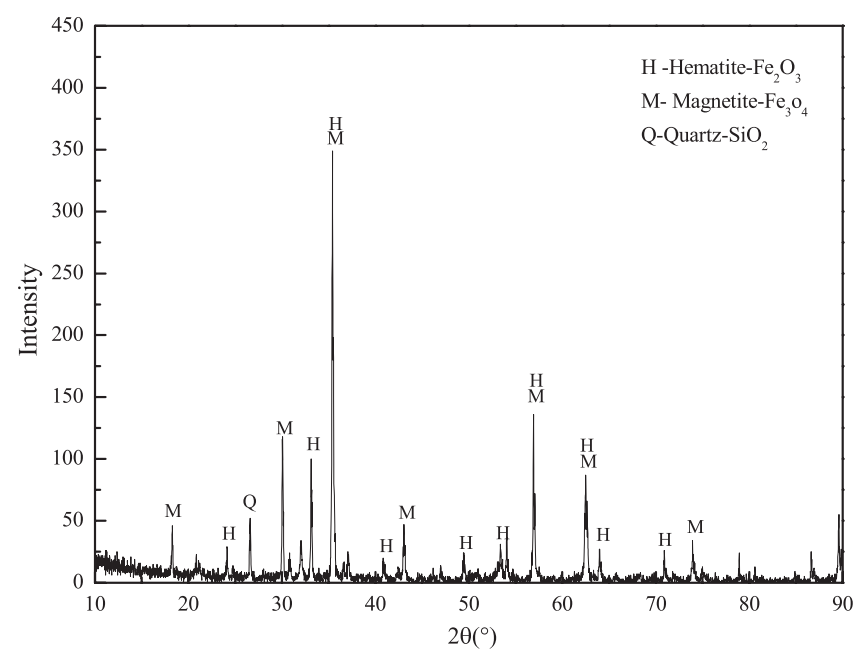

Fig. 1. XRD pattern of the tin-bearing iron concentrates. scanning calorimetry (DSC) of the samples were performed on a thermal analyzer (NETZSCH, STA 449 F3). The typical measurements were performed at a heating rate of $0.17 \mathrm{~K} / \mathrm{s}$ under Ar atmosphere. Chemical composition and mineralogy of the samples were characterized by chemical analysis, scanning electron microscope (SEM), point counting, energy dispersive spectrometer (EDS), and electron probe microanalysis (EPMA). All of the products phase compositions were detected by an X-ray diffraction (Rigaku $\mathrm{D} / \mathrm{max}-3 \mathrm{~B}$ ) with a $\mathrm{Cu}-\mathrm{K} \alpha$ radiation. Spectra were registered between $10^{\circ}$ and $90^{\circ}$ with a step of $8^{\circ}$ and per step of 1 minute. The thermodynamic data of species were given by FactSage thermochemical software. Mathematical expression of the tin removal rate was defined as:

$$
\mathrm{R}=\left(1-\frac{\mathrm{M}_{\mathrm{T}} \times \mathrm{W}_{0}}{\mathrm{M}_{\mathrm{C}} \times \mathrm{W}_{\mathrm{C}}}\right) \times 100 \%
$$

Where, $\mathrm{M}_{\mathrm{C}}$ stands for the mass of tin-bearing iron concentrates used, $\mathrm{W}_{\mathrm{C}}$ for the tin content in the origin tin-bearing iron concentrates, $\mathrm{M}_{\mathrm{T}}$ for the total mass of the roasted residue, $\mathrm{W}_{0}$ for the tin content in the roasted residue.

\section{Thermo-chemical Behavior of the Mixture of Pyrite and Tin-bearing Iron Concentrates}

It has been confirmed by many studies that the decomposition of pyrite proceeds through a multi-step process in the following sequence: ${ }^{18-20)}$

$$
\operatorname{pyrite}\left(\mathrm{FeS}_{2}\right) \rightarrow \operatorname{pyrrhotite}\left(\mathrm{Fe}_{1-\mathrm{x}} \mathrm{S}\right)+\mathrm{S}_{\mathrm{x}} \rightarrow \operatorname{troilite}(\mathrm{FeS})+\mathrm{S}
$$

The above results demonstrate that pyrite can be thermodecomposed into pyrrhotite, troilite, and element sulfur during heat-treatment, all of which have the reduction ability to react with hematite.

Figure 3 shows TG-DSC curves of the mixture of tinbearing iron concentrates and pyrite (addition amounts of 50.00 mass \%) under Ar atmosphere. There are six endothermic peaks in the range of $323.3-1558.3 \mathrm{~K}$ in addition to the dehydration stage approximately at $394.2 \mathrm{~K}$. Each of these peaks corresponds to one weight-loss stage. At 703.8-864.0

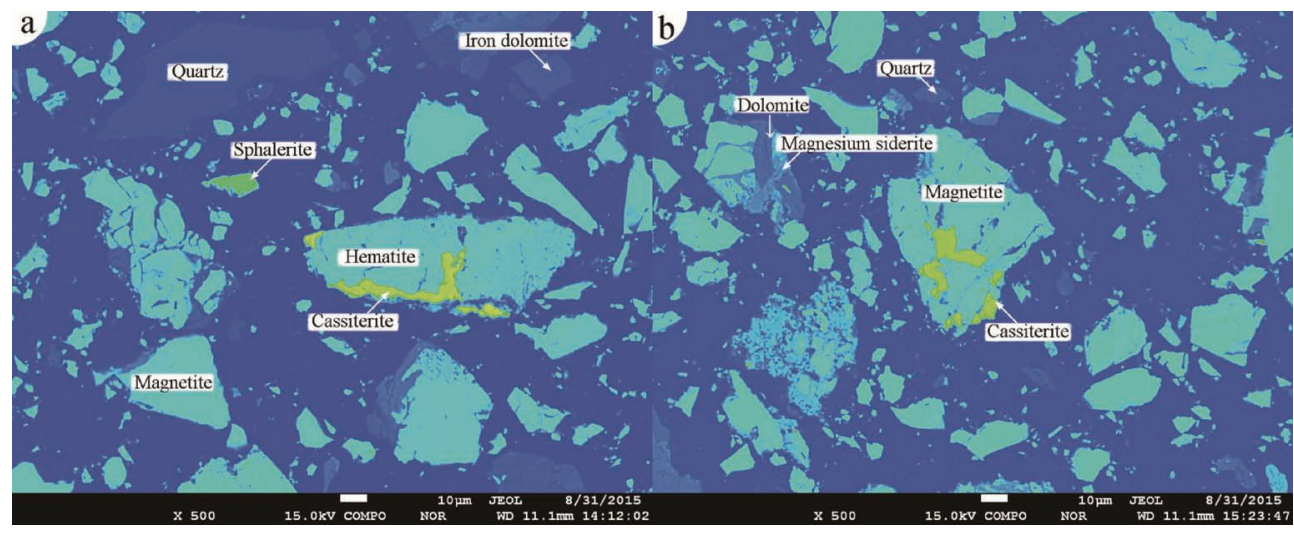

Fig. 2. Mineral phase's distribution obtained by EPMA.

Table 1. Chemical composition of the tin-bearing iron concentrates (mass $\%$ ).

\begin{tabular}{ccccccccccc}
\hline Components & $\mathrm{Fe}$ & $\mathrm{CaO}$ & $\mathrm{SiO}_{2}$ & $\mathrm{Al}_{2} \mathrm{O}_{3}$ & $\mathrm{Sn}$ & $\mathrm{Sb}$ & $\mathrm{Pb}$ & $\mathrm{Zn}$ & $\mathrm{Cu}$ & Others \\
\hline Contents & 64.85 & 1.55 & 0.91 & 0.87 & 0.27 & 0.34 & 0.06 & 0.04 & 0.01 & 30.07 \\
\hline
\end{tabular}




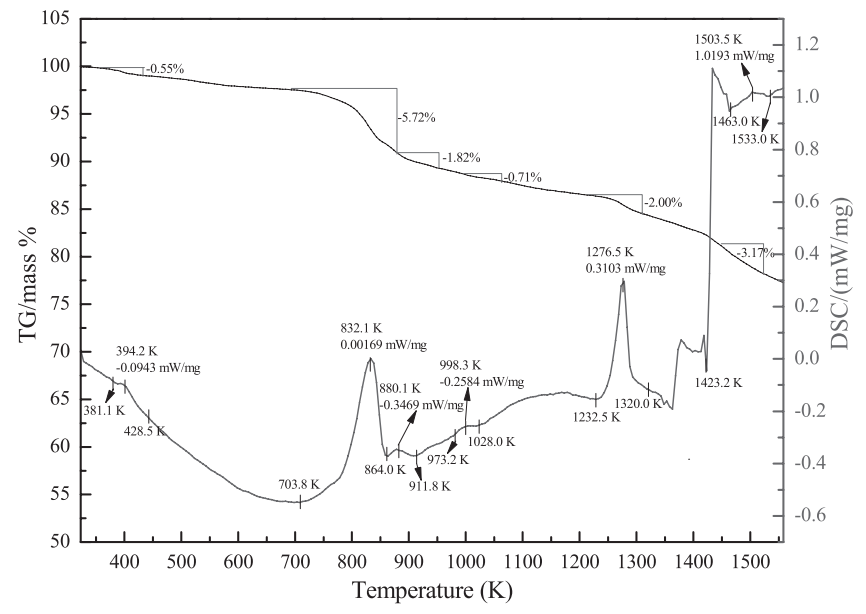

Fig. 3. TG-DSC curves of the mixture of tin-bearing iron concentrates and pyrite (addition amounts of 50.00 mass $\%$ ).

$\mathrm{K}$, the pyrite breaks down to sulphur vapour and pyrrhotite, ${ }^{18-21)}$ corresponding to weight-loss of 5.72 mass $\%$, and there is another weak endothermal peak as a shoulder appearing near $880.1 \mathrm{~K}$, which is related to the reduction of hematite by the decomposed products of pyrite. ${ }^{19)}$ At $1232.5-1320.0 \mathrm{~K}$, the weight-loss (-2.00 mass\%) occurs and the corresponding endothermic peak is attributed to the further decomposition of the primary pyrrhotite before pyrite is completely decomposed. ${ }^{18-21)}$

Reactions that may occur in temperature range of 950.0-1 558.3 K are listed as follows: ${ }^{19,22)}$

$$
\begin{array}{r}
\mathrm{FeS}_{2}=\mathrm{FeS}_{\mathrm{x}}+(2-\mathrm{x}) \mathrm{S}(\mathrm{x}=1-2) \\
\mathrm{S}+6 \mathrm{Fe}_{2} \mathrm{O}_{3}=4 \mathrm{Fe}_{3} \mathrm{O}_{4}+\mathrm{SO}_{2} \ldots \ldots \\
\mathrm{FeS}_{2}+4 \mathrm{Fe}_{2} \mathrm{O}_{3}=3 \mathrm{Fe}_{3} \mathrm{O}_{4}+2 \mathrm{~S} \\
\mathrm{SnO}_{2}+\mathrm{S}_{2}=\mathrm{SnS}+\mathrm{SO}_{2} \\
3 \mathrm{SnO}_{2}+4 \mathrm{FeS}=4 \mathrm{FeO}+3 \mathrm{SnS}+\mathrm{SO}_{2}
\end{array}
$$

Figure 4 shows standard Gibbs free energy changes of these reactions in temperature range of $323.3-1558.3 \mathrm{~K}$. It is known that the reduction of $\mathrm{Fe}_{2} \mathrm{O}_{3}$ by $\mathrm{FeS}_{2}$ involves indirect (Eqs. (2) and (3)) and direct (Eq. (4)) ways. ${ }^{19)}$ It is seen from Fig. 4 that the $\mathrm{Fe}_{2} \mathrm{O}_{3}$ is reduced to $\mathrm{Fe}_{3} \mathrm{O}_{4}$ indirectly by $\mathrm{FeS}_{2}$ above $703.4 \mathrm{~K}$ (Eq. (3)), and directly above $961.9 \mathrm{~K}$. Besides, Fig. 4 shows that the initial temperature for sulfurization of $\mathrm{SnO}_{2}$ to $\mathrm{SnS}$ (Eq. (5)) is about $956.8 \mathrm{~K}$, and the reaction between $\mathrm{FeS}$ and $\mathrm{SnO}_{2}$ (Eq. (6)) occurs hardly since $\mathrm{FeS}$ is stable below $1558.3 \mathrm{~K}$.

Enthalpy changes of the related reactions at temperatures of interest are plotted in Fig. 5, and some transitions during the reaction process (see Fig. 3) are found to be driven by enthalpy. The FeS undergoes a phase transformation from $\mathrm{FeS}(\mathrm{s})$ into $\mathrm{FeS}(1)$ theoretically starting at $1463.0 \mathrm{~K}$ (see Fig. 5), as a result of which there is almost no change in weight but a strong exothermic peak at $1423.2 \mathrm{~K}$ in Fig. 3. Based on the SnS theoretical phase transitions at $1549.2 \mathrm{~K}$ in Fig. 5, $\mathrm{SnS}(\mathrm{l}) \rightarrow \mathrm{SnS}(\mathrm{g})$, the weight-loss of $3.17 \mathrm{mass} \%$ occurring in the range of 1 463.0-1 533.0 K shown in Fig. 3 , may be attributed to the evaporation of $\mathrm{SnS}(\mathrm{g})$.

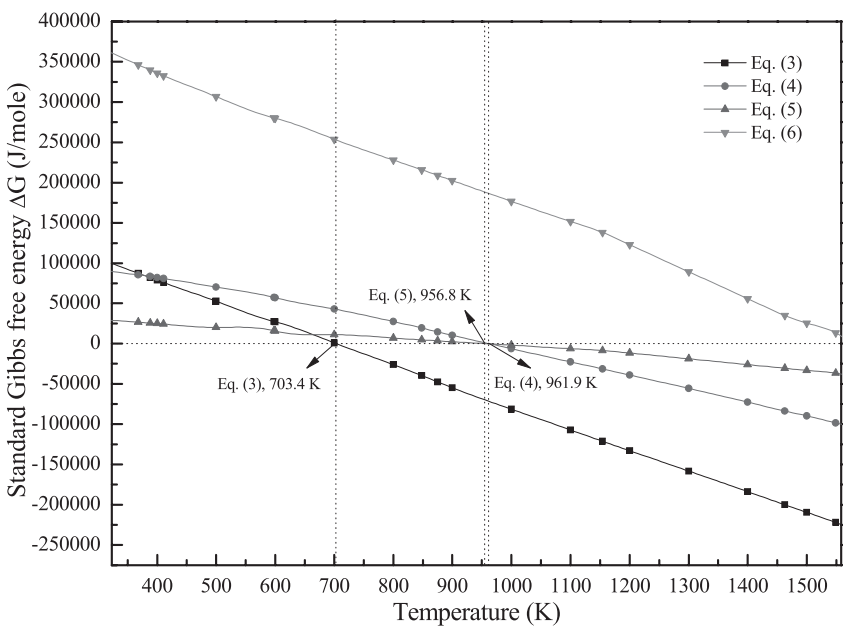

Fig. 4. The standard Gibbs free energy changes of reactions of (3)-(6) with temperature.

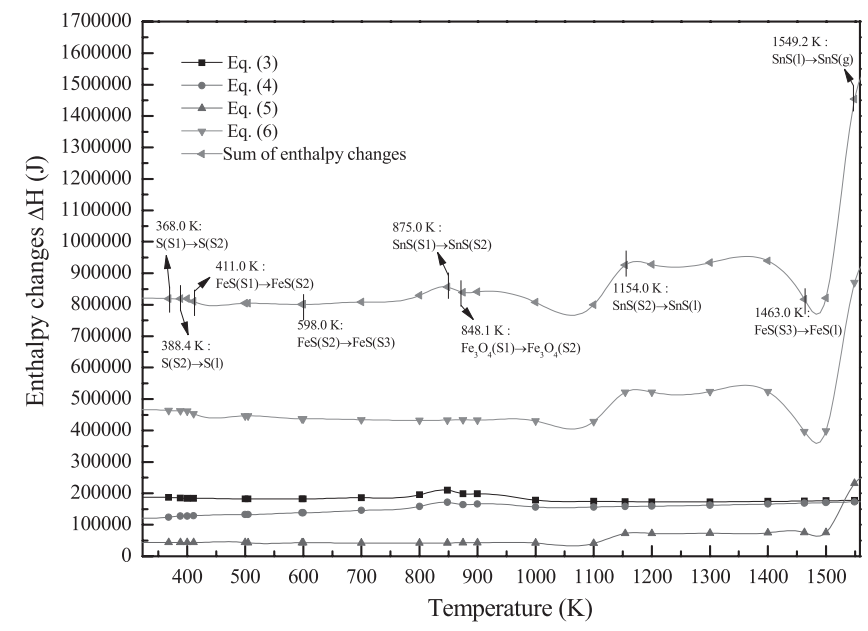

Fig. 5. Enthalpy changes of reaction of (3)-(6) with temperature.

\section{Results and Discussion}

In order to reduce hematite and achieve the purpose of removing tin, it is necessary to optimize the operating parameters of tin-bearing iron concentrates roasted with pyrite. For this purpose, the effects of roasting temperature, time, pyrite addition amounts and particle size of the tinbearing iron concentrates were investigated.

\subsection{Effects of Roasting Temperature and Time}

Under $\mathrm{N}_{2}$ flow rate of $5.00 \times 10^{-6} \mathrm{~m}^{3} / \mathrm{s}$, residence time of $60 \mathrm{~min}$, pyrite addition amounts of 50.00 mass $\%$ and concentrates particle size of $0.075 \mathrm{~mm}$, five roasting temperatures of $1073.0,1123.0,1273.0,1373.0$ and $1473.0 \mathrm{~K}$ were chosen for studying the effects on the iron phases reduction and tin removal rate.

The pyrite decomposes into $\mathrm{Fe}_{1-\mathrm{x}} \mathrm{S}$ and $\mathrm{S}_{\mathrm{x}}$ starting at 703.8 K (see Fig. 3), and the iron phase's reduction, shown as Eqs. (3) and (4), can be carried out at the roasting temperature (1 073.0-1 473.0 K) according to Fig. 4. XRD patterns of the roasted products at different temperatures are presented in Fig. 6 ('Unroasted' is tin-bearing iron concentrates without pyrite addition). It is obvious that temperature is an important factor for the reduction of hematite to 


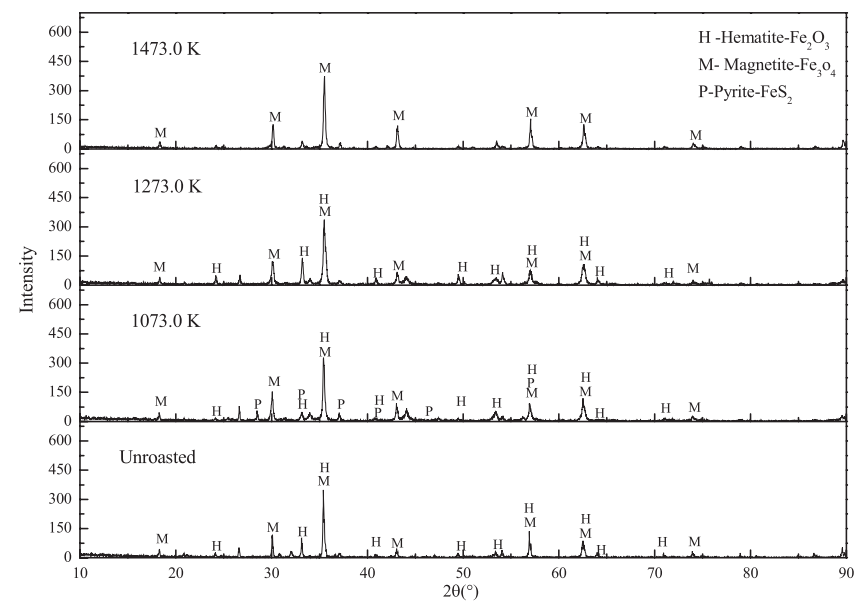

Fig. 6. XRD patterns of the roasted products at different temperatures.

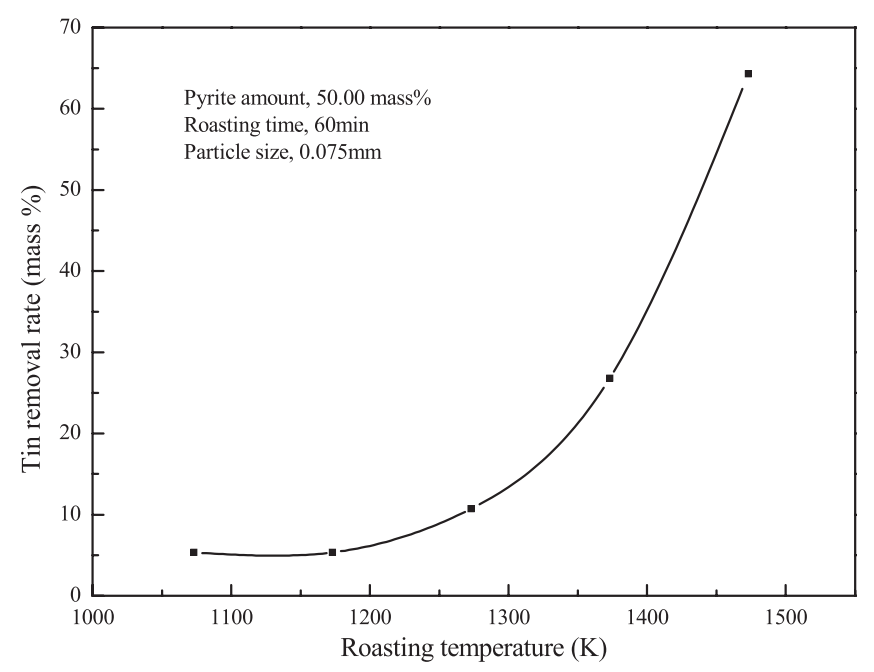

Fig. 7. Effects of roasting temperature on the tin removal rate.

magnetite. Temperature increase improves the reaction rate between hematite and decomposed products of pyrite. The peak intensity of magnetite (reduction products) gradually increases and that of hematite decreases with temperature (see Fig. 6), and the transformation is basically completed when temperature reaches $1473.0 \mathrm{~K}$.

The pyrite cannot be further decomposed when temperature is relatively low, ${ }^{18)}$ and the formation of $\mathrm{S}$ is little, causing the tin removal reaction (Eq. (5)) also happens little at a low temperature. Figure 7 shows that tin removal rate increases slightly with temperature raised from 1073.0 to $1273.0 \mathrm{~K}$, but it increases obviously to 64.29 mass \% with temperature raised further to $1473.0 \mathrm{~K}$. At a higher temperature, the formation of tin sulphide $(\mathrm{SnS})$ is promoted, and some $\mathrm{SnS}$ (l) can be transferred to $\mathrm{SnS}(\mathrm{g})$ which is easy to volatilize, both being favorable to increasing tin removal rate. In order to reduce hematite and remove tin as much as possible, roasting temperature is fixed at $1473.0 \mathrm{~K}$.

Figure 8 shows the hematite can partially be reduced into magnetite after being roasted for $40 \mathrm{~min}$, and this transformation is completed with residence time prolonged further to $60 \mathrm{~min}$. Figure 9 shows variations of tin removal rate as a function of roasting time. The tin removal rate increases gradually in the primary $60 \mathrm{~min}$, from $1.79 \mathrm{mass} \%$ to 64.29



Fig. 8. XRD patterns of the products roasted for different time.



Fig. 9. Effect of residence time on the tin removal rate.

mass $\%$, and then remains nearly constant. To decrease the process energy consumption and improve tin removal rate, residence time is fixed at $60 \mathrm{~min}$.

\subsection{Effects of Pyrite Amount}

The FactSage 6.4 was used to calculate the equilibrium of roasted products in Gibbs free energy minimization under isothermal, isobaric and fixed mass conditions. Required data for computation were taken from FactPS database of the programme.

In Equilib program of FactSage, $\mathrm{Fe}_{2} \mathrm{O}_{3}(\mathrm{~s})$ (32.425 g), $\mathrm{Fe}_{3} \mathrm{O}_{4}(\mathrm{~s})(32.425 \mathrm{~g}), \mathrm{CaO}(\mathrm{s})(1.55 \mathrm{~g}), \mathrm{SiO}_{2}(\mathrm{~s})(0.91 \mathrm{~g})$, $\mathrm{Al}_{2} \mathrm{O}_{3}$ (s) (0.87 g), $\mathrm{SnO}_{2}$ (s) (0.71 g), $\mathrm{FeS}_{2}(\mathrm{~s})$ and $\mathrm{N}_{2}$ (g) were selected as reactant precursors, where $\mathrm{N}_{2}(\mathrm{~g})$ was an inert gas to strict control the retained content of $\mathrm{O}_{2}$ in the atmosphere. The calculations were performed in $100 \mathrm{~g}$ tin-bearing iron concentrates with variable pyrite amounts added under temperature of $1473.0 \mathrm{~K}$ and atmosphere pressure of $1 \mathrm{~atm}$. The phases of iron sulfide $(\mathrm{FeS})$, magnetite $\left(\mathrm{Fe}_{3} \mathrm{O}_{4}\right)$, hematite $\left(\mathrm{Fe}_{2} \mathrm{O}_{3}\right)$, cassiterite $\left(\mathrm{SnO}_{2}\right)$, tin sulphide $(\mathrm{SnS})$, sulfur dioxide $\left(\mathrm{SO}_{2}\right)$ and element sulfur $\left(\mathrm{S}_{2}\right)$ were assumed to be present in the roasted products and results of phase's equilibrium are present in Fig. 10. It shows that increase of pyrite amounts improves formation of $\mathrm{Fe}_{3} \mathrm{O}_{4}$ and $\mathrm{SnS}$ under 
pyrite amounts less than 5.00 mass $\%$. When pyrite amounts increase over 5.00 mass $\%$, the $\mathrm{Fe}_{3} \mathrm{O}_{4}$ amounts decrease and FeS amounts increase obviously.

The mixtures of tin-bearing iron concentrates and pyrite at different quality ratios were roasted at $1473.0 \mathrm{~K}$ for 60 min. Figure 11 shows that almost all diffraction peaks are assigned to magnetite when pyrite addition is 5.00 mass $\%$ and the FeS phase appears and increases with pyrite

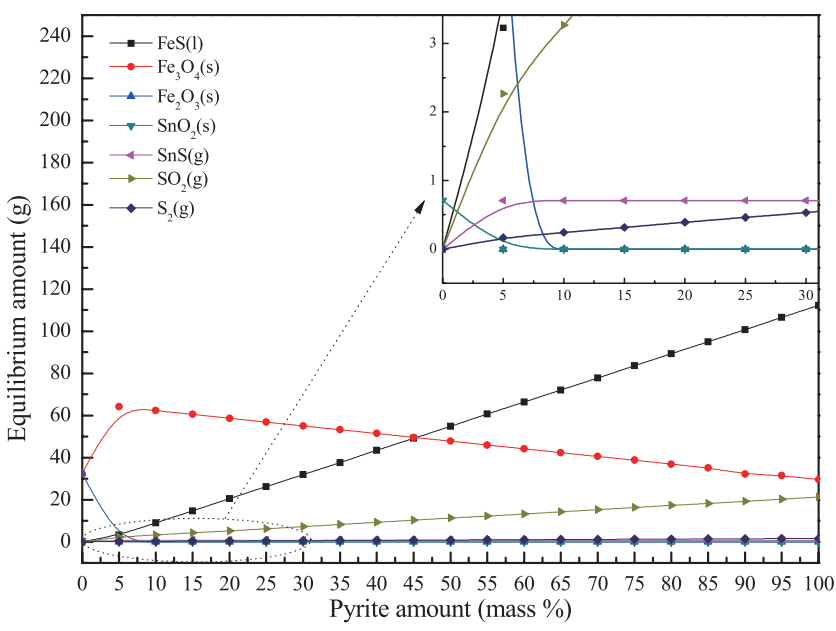

Fig. 10. Equilibrium amounts of species in roasted products as a function of pyrite amounts.



Fig. 11. XRD patterns of the products with different pyrite addition amounts. amounts from 5.00 mass $\%$ to 100.00 mass $\%$. These results are in agreement with those obtained from Fig. 10. When pyrite amounts exceed 5.00 mass $\%$, some of the produced magnetite will be sulfurated to $\mathrm{FeS}$, as a result of which magnetite amounts decrease and FeS amounts increase.

Figure 12 shows that tin removal rate increases sharply with pyrite addition from 0.00 mass $\%$ to 5.00 mass $\%$ and remains nearly constant as pyrite addition increases further. $\mathrm{SnO}_{2}$ (s) can be transformed into $\mathrm{SnS}$ (g) completely based on the equilibrium-analysis (see Fig. 10), and there will be no tin residue observed in the roasted products if $\mathrm{SnS}(\mathrm{g})$ volatilizes completely. However, the max tin removal rate is only about 72.86 mass $\%$ in the roasting experiments (see Fig. 12).

With pyrite addition amounts of 50.00 mass $\%$, the mixture was roasted at $1473.0 \mathrm{~K}$ for $60 \mathrm{~min}$, and a scanning electron microscope provided with a detector of back scattered electrons (SEM-BSE) was used to characterize the products morphology. Some pictures were made (Figs. 13(a) and 13(b)), and EDS analyses (Fig. 14) for the selected areas were performed. Some holes can be observed in the products morphology (see Fig. 13(a)), and the Fe-O, $\mathrm{Fe}-\mathrm{O}-\mathrm{Sn}-\mathrm{S}$, and $\mathrm{Fe}-\mathrm{S}-\mathrm{O}$ phases are found to be formed at the surface of these holes deduced from Figs. 13(b) and 14, appearing to be spherical particles. Taking into consideration of equilibrium-analysis and effects of pyrite amounts

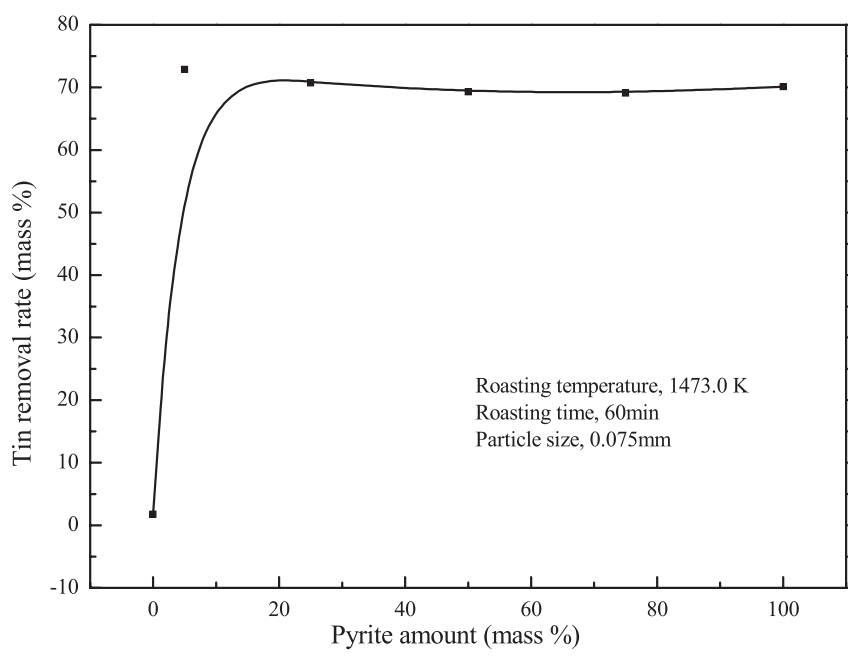

Fig. 12. Effect of pyrite amounts on the tin removal rate.

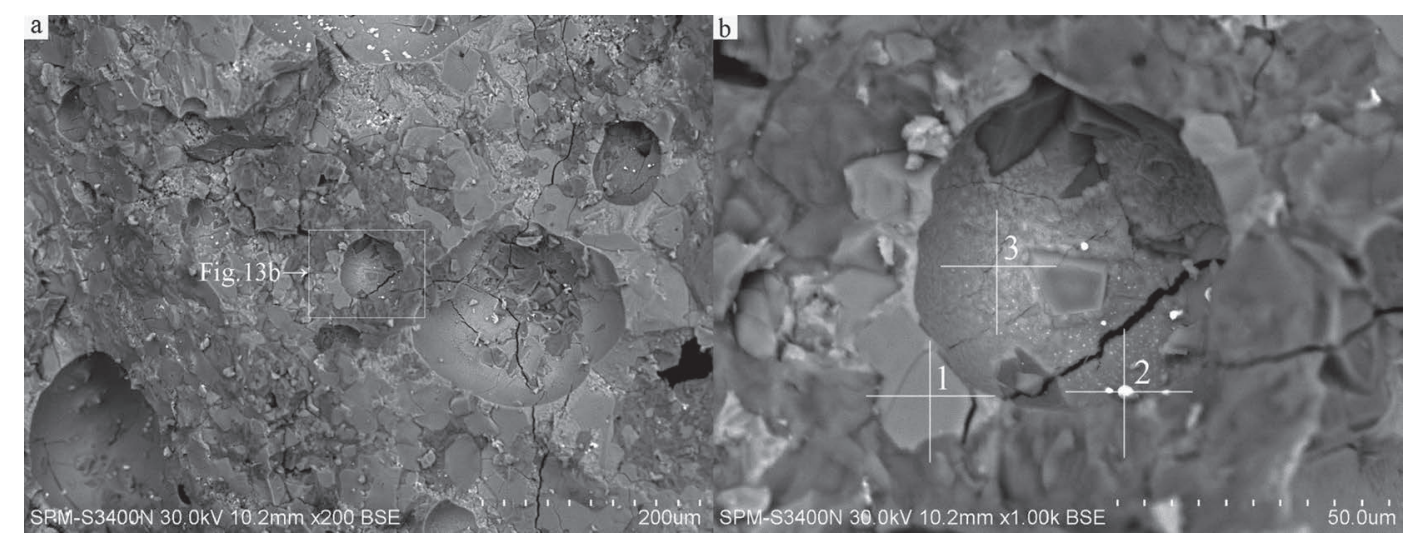

Fig. 13. SEM photos of the roasted products with pyrite addition amounts of 50.00 mass $\%$. 


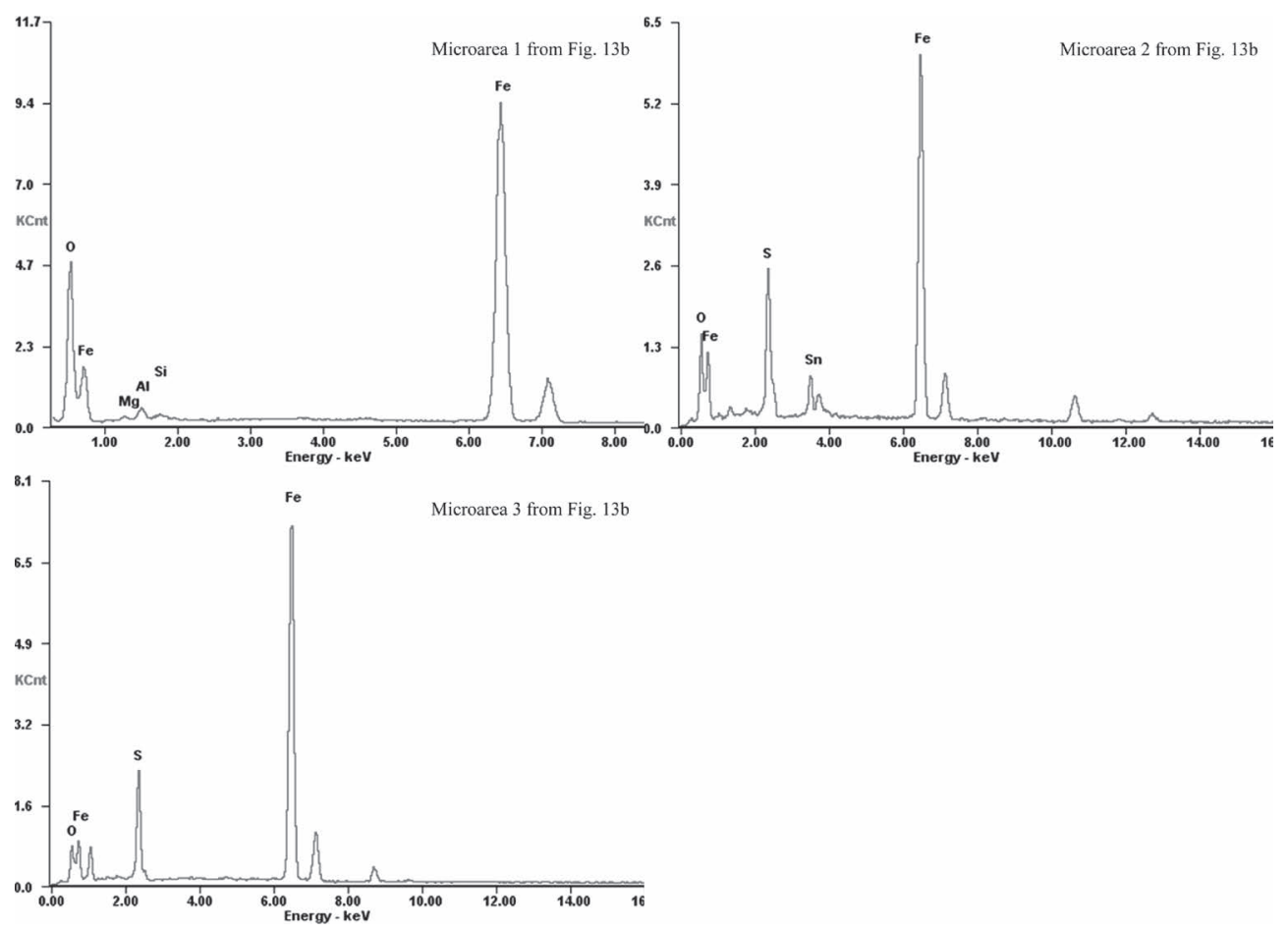

Fig. 14. EDS analyses of 1,2 and 3 microareas of the SEM photos.

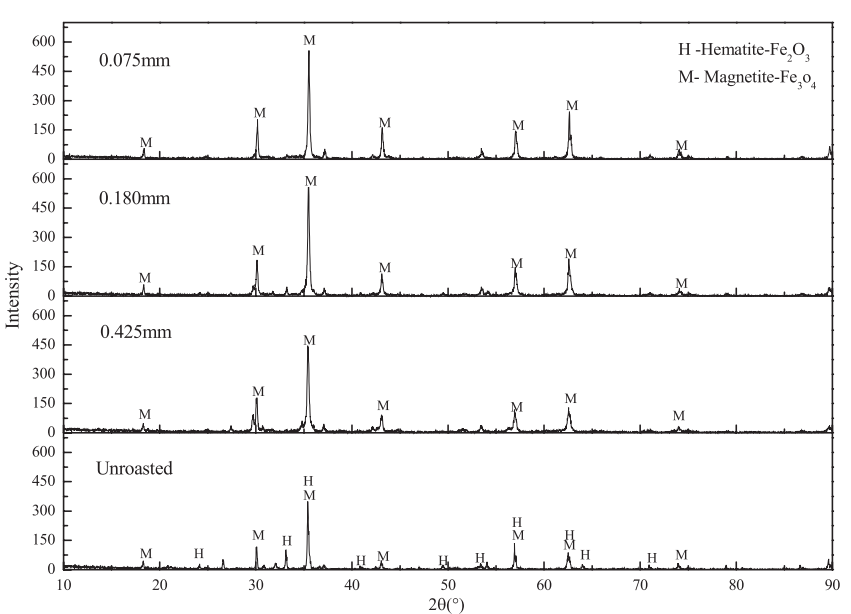

Fig. 15. XRD patterns of the roasted products at different particle sizes of tin-bearing iron concentrates.

on the tin removal rate, it could be stated that the formation of these holes is caused by the aggregation of gaseous $\mathrm{SnS}$, $\mathrm{SO}_{2}$ and $\mathrm{S}_{2}$ within the mixture of iron sulfide $(\mathrm{FeS})$ liquid and magnetite particles. ${ }^{23,24)}$

In order to decrease the formation amounts of FeS which hinders the evaporation of $\mathrm{SnS}(\mathrm{g})$, pyrite addition amounts are fixed at $5.00 \%$.

\subsection{Effects of Particle Size}

Surface area of reaction particles increases as the particle size decrease, and it is beneficial to increasing iron reduction and tin sulfidation rates. Figure 15 shows phase composition of the products with 5.00 mass $\%$ pyrite addition and roasted for $60 \mathrm{~min}$ at $1473.0 \mathrm{~K}$, the results show that peak intensity of the magnetite increases obviously while tinbearing iron concentrates average particle size decreases from $0.425 \mathrm{~mm}$ to $0.075 \mathrm{~mm}$. Obviously, the effect of its particle size on the tin removal rate is very small (shown in

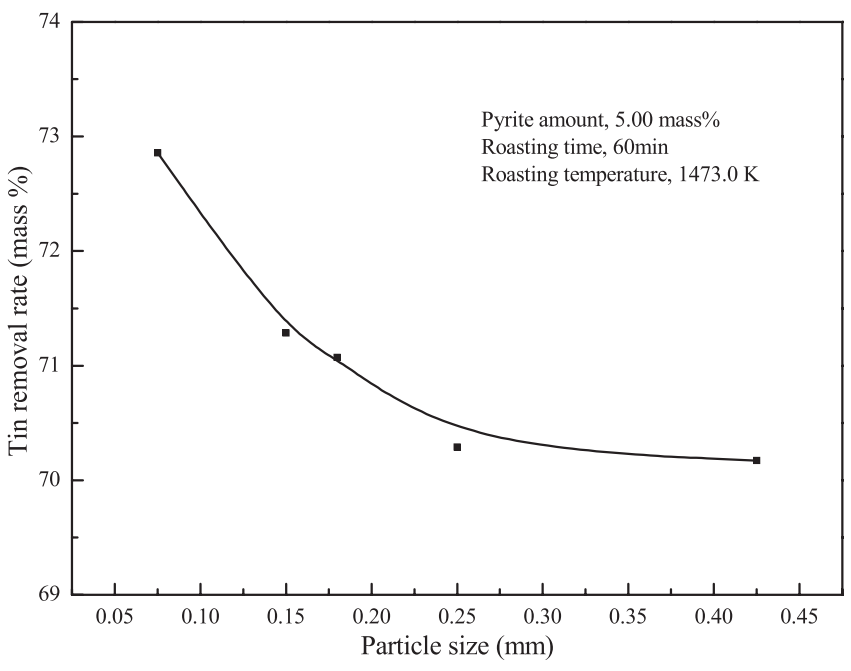

Fig. 16. Effect of tin-bearing iron concentrates particle size on the tin removal rate.

Fig. 16) due to its low content, although it has been changed during the reduction roasting process.

As discussed above, the optimum parameters are established as follows: roasting temperature, $1473.0 \mathrm{~K}$; roasting time, $60 \mathrm{~min}$; pyrite amounts, 5.00 mass\%; particle size, $0.075 \mathrm{~mm}$. After roasted, the hematite in tin-bearing iron concentrates can be reduced to magnetite completely, meanwhile, the tin content is decreased from 0.27 mass $\%$ to 0.07 mass \% (tin removal rate of 72.86 mass\%). The roasted concentrates can meet the standard of BF ironmaking, which requires $\mathrm{Sn}$ content in the iron ores less than 0.08 mass \%. ${ }^{6}$ ) Besides, the tin removed can be recycled through smoke dust collection. It indicates the decomposed products of the pyrite can pre-reduce hematite into magnetite and achieve the purpose of $\mathrm{Sn}$ effective removal from tin-bearing iron concentrates. 


\section{Conclusions}

The reduction of hematite to magnetite and effective removal of $\mathrm{Sn}$ from the tin-bearing iron concentrates through co-roasting with pyrite are feasible. The factors including pyrite amounts, roasting temperature, residence time and particle size of tin-bearing iron concentrates have important influences. The hematite in tin-bearing iron concentrates can be reduced to magnetite directly by $\mathrm{FeS}_{2}$ above $961.9 \mathrm{~K}$ and indirectly above $703.4 \mathrm{~K}$. The initial temperature for sulfurization of $\mathrm{SnO}_{2}$ to $\mathrm{SnS}$ is about $956.8 \mathrm{~K}$ using $\mathrm{FeS}_{2}$, and the reaction between $\mathrm{FeS}$ and $\mathrm{SnO}_{2}$ occurs hardly since FeS is stable below $1558.3 \mathrm{~K}$.

In a certain range, the tin removal and iron phases reduction rates both increase with roasting temperature, residence time and pyrite amounts. When pyrite amounts exceed 5.00 $\operatorname{mass} \%$, some of the produced magnetite will be sulfurated to $\mathrm{FeS}$ and the evaporation of $\mathrm{SnS}(\mathrm{g})$ will be obstructed. As a result, magnetite formation and tin removal rate decrease. The optimum conditions are established as follows: roasting temperature, $1473.0 \mathrm{~K}$; roasting time, $60 \mathrm{~min}$; pyrite amount, 5.00 mass \%; particle size, $0.075 \mathrm{~mm}$. After roasted under these conditions, the hematite in tin-bearing iron concentrates can be reduced into magnetite completely, meanwhile, the tin content is decreased from 0.27 mass $\%$ (unroasted sample) to 0.07 mass $\%$. It can meet the standard of $\mathrm{BF}$ ironmaking, which requires $\mathrm{Sn}$ content in the iron ores less than 0.08 mass $\%$, and the roasted concentrates can be used directly as blast furnace iron-making materials. In addition, the tin removed can be recycled through smoke dust collection.

\section{Acknowledgments}

The authors wish to express thanks to National Science Fund for Distinguished Young Scholars (51304092) for financial support of this research.

\section{REFERENCES}

1) C. X. Xie, H. M. Li, R. J. Wang, K. Y. Xiao, L. Sun and Y. L. Liu: Geol. Bull. China, 28 (2009), 80 (in Chinese).

2) J. Liu and S. Y. Jin: China Min. Mag., 18 (2009), 1 (in Chinese).

3) C. Xie: Hunan Nonferr. Met., 11 (1996), 13 (in Chinese).

4) T. Jiang, Y. B. Zhang, Z. C. Huang and G. H. Li: Trans. Nonferr. Met. Soc. China, 15 (2005), 902 (in Chinese).

5) Y. B. Zhang, T. Jiang, G. H. Li, Z. C. Huang and Y. F. Guo: Ironmaking Steelmaking, 38 (2011), 617.

6) Y. B. Zhang, Z. J. Su, Y. L. Zhou, G. H. Li and T. Jiang: Int. J. Miner. Process., 124 (2013), 15.

7) W. S. Huang: Tin, Metallurgical Industry Publishing Company. Beijing, (2001), 291.

8) G. Z. Qiu, T. Jiang, J. C. Xu and Y. Z. Cai: Cold-bonded Pellet Direct Reduction, Central South University Press. Changsha, (2001), 184.

9) D. Huang, Y. B. Zhang, G. H. Han, G. H. Li and T. Jiang: 39th TMS Annu. Meeting and Expo., Vol. 1, TMS, Warrendale, PA, (2010), 393.

10) T. Jiang, Y. B. Zhang, G. Q. He, G. H. Li and Z. C. Huang: Proc. 24th Int. Mineral Processing Cong. (IMPC), IMPC, Beijing, (2008), 3952.

11) Y. B. Zhang, G. H. Li, T. Jiang, Y. F. Guo and Z. C. Huang: Int. J. Miner. Process., 110-111 (2012), 109.

12) A. W. Fletcher, D. V. Jackson and A. G. Valentine: Inst. Min. Metall. Trans, 76 (1967), 145.

13) M. C. Mayoral, M. T. Izquierdo, J. M. Andres and B. Rubio: Thermochim. Acta, 390 (2002), 103.

14) P. Baguley, D. H. John and P. C. Hayes: Metall. Trans. B, 14 (1983), 513.

15) J. P. Gaviría, A. Bohé, A. Pasquevich and D. M. Pasquevich: Phys. B, 389 (2007), 198.

16) A. Pineau, N. Kanari and I. Gaballah: Thermochim. Acta, 447 (2006), 89.

17) P. K. Strangway and H. U. Ross: Can. Metall. Q, 5 (1966), 221.

18) G. Hu, K. Dam-Johansen, S. Wedel and J. P. Hansen: Prog. Energy Combust. Sci., 32 (2006), 295.

19) Y. Y. Liu, B. C. Zhao, Y. Tang, P. Y. Wan, Y. G. Chen and Z. J. Lv: Thermochim. Acta, $\mathbf{5 8 8}$ (2014), 11.

20) S. Gornostayev, J. Härkki and O. Kerkkonen: Fuel, 88 (2009), 2032.

21) P. Walder and A. D. Pelton: J. Phase Equilib. Diffus., 26 (2005), No. $1,23$.

22) L. Li, Z. J. Qiu, H. Wang, Y. G. Wei, B. Liao and X. L. Sang: China $J$ Nonferrous Met., 24 (2014), 519 (in Chinese).

23) S. Giraud, T. Duffar, E. Pihan and A. Fave: J. Cryst. Growth, 432 (2015), 83 .

24) H. F. Gu, Q. Chen, H. J. Wang and H. Q. Zhang: Appl. Therm. Eng., 91 (2015), 938. 